\title{
Development of Natural Gas Demonstrator Based on an Urban Vehicle with a Down-Sized Turbocharged Engine*
}

\author{
R. Tilagone ${ }^{1}$ and S. Venturi ${ }^{1}$ \\ 1 IFP-Lyon, BP 3, 69390 Vernaison - France \\ e-mail: richard.tilagone@ifp.fr - stephane.venturi@ifp.fr \\ * From the conference proceedings "Which Fuels For Low- $\mathrm{CO}_{2}$ Engines?" published in full by Éditions Technip
}

\begin{abstract}
Résumé - Développement d'un démonstrateur gaz naturel sur la base d'un véhicule urbain doté d'un moteur suralimenté - L'objectif principal de ce projet est de confirmer le potentiel du gaz naturel en tant que carburant, pour les applications urbaines notamment. Un véhicule de démonstration utilisant uniquement le CNG (compressed natural gas) comme carburant à été développé, en se basant sur un véhicule urbain existant. Le but est de parvenir à des émissions de $\mathrm{CO}_{2}$ faibles, avec un niveau maximal de $100 \mathrm{~g} / \mathrm{km}$ sur le cycle de conduite MVEG (motor vehicles emissions group), tout en respectant les niveaux d'émissions de polluants imposés par la norme Euro IV.

L'accent est mis par les partenaires de ce projet sur le maintien de l'agrément général du véhicule proche de la version essence de référence, telles la vitesse maximale et l'accélération. Pour ces raisons, le choix s'est porté sur une Smart équippée d'un moteur turbocompressé à faible cylindrée, permettant d'obtenir de faibles émissions de $\mathrm{CO}_{2}$ et nécessaire pour maintenir le couple et la puissance proches des valeurs cibles.

Dans un premier temps, les composants moteur spécifiques au CNG (pistons, bielle, rampe de gaz, etc.) ont été réalisés. Les réglages du moteur et la suralimentation ont ensuite été optimisés sur banc d'essai afin d'obtenir le meilleur compromis en termes de puissance, de consommation et d'émissions de polluants. La dernière étape a consisté à la calibration du moteur, d'abord sur banc d'essai puis sur véhicule. Cette optimisation a permis de respecter les normes d'émission Euro IV tout en offrant un agrément de conduite satisfaisant.
\end{abstract}

Abstract - Development of Natural Gas Demonstrator Based on an Urban Vehicle with a Down-Sized Turbocharged Engine - The main objective of this project is to confirm the high efficiency of compressed natural gas $(C N G)$ fuel when used in urban conditions. For this purpose, a demonstrator vehicle using only $C N G$ fuel has been developed when modifying an existing gasoline urban vehicle. The target is to achieve low $\mathrm{CO}_{2}$ emissions with a maximum level of $100 \mathrm{~g} / \mathrm{km}$ on the motor vehicles emissions group (MVEG) driving cycle, while keeping pollutant emissions below Euro IV level.

In addition, partners involved focus to maintain vehicle behaviours as maximum vehicle speed and acceleration close to standard gasoline version. For these reasons, a Smart car has been chosen offering, on one hand, a small displacement engine useful to obtain low $\mathrm{CO}_{2}$ emissions (downsizing approach), and on another hand, turbocharger characteristic necessary to maintain torque and power outputs in accordance with expectation. 
The first step was dedicated to CNG specific engine parts design (pistons, connecting rod, crankshaft, camshaft, etc.) in order to optimise CNG configuration. During the following steps, the engine has been optimised on a test bench. Valve timing and turbocharger selection have been optimised in order to obtain the best trade-off in terms of power consumption and pollutants. The final step has been to calibrate the engine, firstly on the test bench and secondly on the vehicle. This work allows coping with Euro IV emissions level with optimised catalyst light-off, transient running conditions, drive-ability, etc.

\section{INTRODUCTION}

Reduction of greenhouse gases emissions remains one of the most important challenges stakes for the coming decades, involving all energy consumers and especially the industrial actors, although the need to make better use of energy is not appreciated to the same extent by all industrial countries.

For the automotive sector, the European car manufacturers' commitment (reduction of the average fuel consumption for new vehicles to $140 \mathrm{~g}$ of $\mathrm{CO}_{2}$ produced per kilometre by 2008) appears to be a valuable contribution towards meeting the recommendations of the European Commission.

A sharp $\mathrm{CO}_{2}$ emission reduction requires efforts both to reduce vehicle fuel consumption, and to widen the use of fuel with advantageous molecular hydrogen to carbon $(\mathrm{H} / \mathrm{C})$ ratio.

Alongside vehicle optimisation itself, improving engine efficiency remains the main target. Reduction of engine displacement volume (commonly named downsizing) is an efficient way to achieve this target. Due to its interesting chemical properties, natural gas can be used to achieve low carbon dioxide levels (H/C ratio close to 4), while at the same time maintaining high thermal efficiency through dedicated engine development.

The main objective of this project is to confirm (with a dedicated demonstrator vehicle) the high efficiency of CNG fuel when used in urban conditions. The target is to achieve low $\mathrm{CO}_{2}$ emissions with a maximum level of $100 \mathrm{~g} / \mathrm{km}$ on the MVEG driving cycle, while keeping pollutant emissions below Euro IV level.

First, this paper describes the optimisation work done on the Smart $600 \mathrm{cc}$ engine for the gaseous version, and the Smart vehicle itself (adaptation of driveline transmission is not presented in this paper). Then, results obtained on test bench with specific electronic control unit developed by IFP have been compared to gasoline ones. Finally, the performances on a chassis dynamometer bench are introduced.

\section{NATURAL GAS AS ALTERNATIVE FUEL}

As one of the most promising fossil energy resources, NG is widely used for transportation and more especially for automotive applications.
Some chemical properties of gaseous fuel are advantageous for emissions and consumption trade-off; others require specific adaptations due to gas phase in normal condition of use. Those that most distinguish NG are highlighted.

High research octane number (RON), higher than 130 as compared to 95 for European Eurosuper premium gasoline. For spark ignited combustion this results in a reduced tendency towards engine knock. Thanks to this characteristic, a NG engine can be designed with a higher compression ratio than for common gasoline combustion, resulting in better fuel efficiency. The following relation directly links the compression ratio $(\varepsilon)$ to the thermal efficiency $(\eta)$. Symbol $(\gamma)$ represents the specific heat capacity of mixture.

$$
\gamma / / \Rightarrow\left[\eta=1-\varepsilon^{\gamma}\right]
$$

The possibility to run with maximum best torque (MBT) advance limits the exhaust gas temperature and avoids use of the strategy applied to gasoline engines, which consists in cooling down the exhaust gases by increasing the air to fuel equivalence ratio. Continuous stoichiometric conditions, best torque spark advance and high compression ratio are key factors to enhance thermal efficiency and drastically reduce exhaust emissions, especially for turbocharged engine.

The main component of natural gas is methane (between 80 to $99 \%$ ). Thus, $\mathrm{H} / \mathrm{C}$ molecular ratio from natural gas is close to 4 , higher than gasoline (around 1.85 ). This property generates a reduction of $\mathrm{CO}_{2}$ emissions up to $23 \%$ for the same engine efficiency (of course this value depends on natural gas composition) (Table 1).

TABLE 1

Theoretical $\mathrm{CO}_{2}$ emissions for stoichiometric combustion

\begin{tabular}{l|cc|c|cc}
\hline & \multicolumn{2}{|c|}{$\begin{array}{c}\mathrm{CO}_{2} \\
(\mathrm{~g} / \mathrm{g} \text { fuel })\end{array}$} & $\begin{array}{c}\mathrm{LHV} \\
(\mathrm{kJ} / \mathrm{kg})\end{array}$ & \multicolumn{2}{c}{$\begin{array}{c}\mathrm{CO}_{2} \\
(\mathrm{~g} / \mathrm{kJ}) \times 10^{3}\end{array}$} \\
\hline $\mathrm{NG}$ & 2.75 & $-13.5 \%$ & 48450 & 56.8 & $-23.7 \%$ \\
Gasoline & 3.18 & 0 & 42690 & 74.5 & 0 \\
Diesel fuel & 3.17 & $-0.3 \%$ & 42770 & 74.1 & $-0.5 \%$ \\
\hline
\end{tabular}

Taking into account the necessary improvements on engine and vehicle to fulfil the 2008 or 2012 commitments for $\mathrm{CO}_{2}$ emissions (European cars on the road should emit $140 \mathrm{~g} / \mathrm{km}$ then $120 \mathrm{~g} / \mathrm{km}$ ), natural gas reveals itself as an 
efficient solution suitable with today's technologies. From today's European performance ( $\left.160 \mathrm{~g} \mathrm{CO}_{2} / \mathrm{km}\right)$, gasoline consumption should be reduced by $14 \%$ in the next 4 years; this does not appear easy, taking into account gains already obtained on small gasoline and Diesel vehicles on the market. In addition, recent surveys on well-to-wheel analysis confirm the positive impact of natural gas on $\mathrm{CO}_{2}$ reduction (MIT, Eucar-Concawe, IFP, JCAE, etc.).

Natural gas engines shows a significant reduction of pollutant emissions compared to the corresponding gasoline baseline engine; the gaseous state of this fuel avoids wall wetting effects on intake manifold and cylinder liner especially at cold start conditions. Thus, it induces fuel consumption savings and above all, unburned hydrocarbons emissions reductions. Concerning unburned hydrocarbons, the reduction comes also from oil film adsorption-desorption phenomena, which is one of the main sources of unburned fuel. The percentage of $\mathrm{HC}$ emissions from this source is smaller for methane than for gasoline. Finally, the raw $\mathrm{HC}$ emissions should be $50 \%$ lower than those of the gasoline baseline engine are.

Few intermediate operations are necessary to use NG in vehicles (no refining). Its composition, when delivered from the natural gas grid, depends on output well location and also on time (in accordance with suppliers' strategy). This variation affects its combustion characteristics. In Figure 1, air/fuel ratio, lower heating value (LHV) and knock Index are plotted for one calendar month. Variations are important, but fortunately they do not affect the energy content for a given equivalence ratio as shown in Figure 2; only the gas flow sprayed out from injector varies.

Whatever the gas composition, the rated power from an engine equipped with an air/fuel ratio close-loop control system does not undergo gas variations.

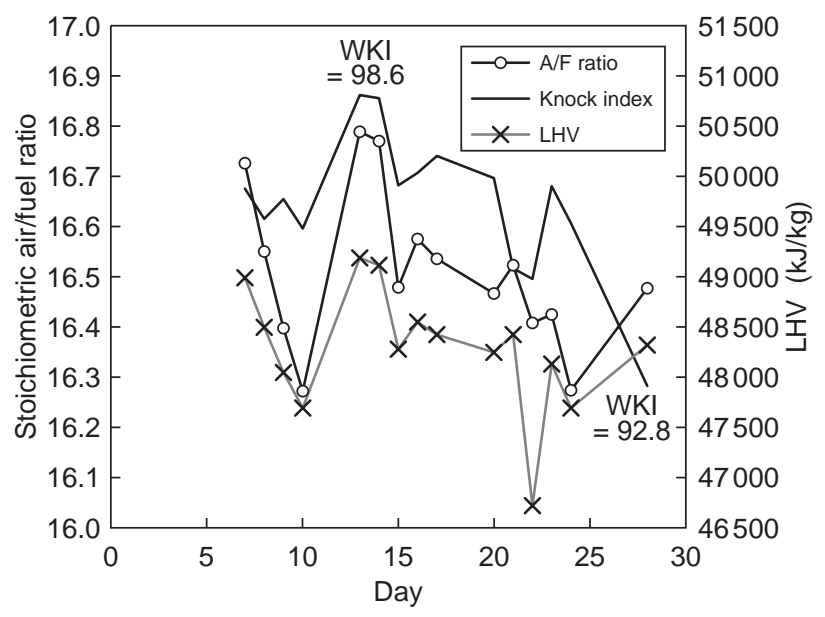

Figure 1

Air/fuel ratio, LHV and knock index variation during one month.
Volumetric LHV of NG is very low compared to liquid fuels (Table 2). For gaseous fuels a high capacity tank and high pressure are necessary to store the energy needed to achieve a competitive driving range.

For instance, at a storage pressure of $20 \mathrm{MPa}$, the volume necessary for the same energy on board is four times greater compared to gasoline; furthermore, tank implementation on chassis vehicle is not so simple.

TABLE 2

Energy per storage volume for common fuel

\begin{tabular}{l|c|c|c|c|c}
\hline & $\begin{array}{c}\text { Density } \\
\mathrm{kg} / \mathrm{m}^{3}\end{array}$ & $\begin{array}{c}\mathrm{LHV} \\
\mathrm{kJ} / \mathrm{kg}\end{array}$ & $\begin{array}{c}\text { Energy } \\
\mathrm{MJ} / \mathrm{m}^{3}\end{array}$ & $\begin{array}{c}\text { Volume } \\
\text { (for same } \\
\text { energy) }\end{array}$ \\
\hline Gasoline & 750 & 42690 & 32020 & & \\
\hline Diesel fuel & 835 & 42770 & 35710 & $+11 \%$ & $\times 0.9$ \\
\hline $\begin{array}{l}\text { Gaseous methane } \\
1013 \mathrm{hPa}, 273 \mathrm{~K}\end{array}$ & 0.716 & 50010 & 36 & $-100 \%$ & $\times 889$ \\
\hline $\begin{array}{l}\text { Gaseous methane } \\
20 \mathrm{Mpa}, 293 \mathrm{~K}\end{array}$ & $\begin{array}{c}173 \\
\text { (AGA8) }\end{array}$ & 50010 & 8652 & $-73 \%$ & $\times 3.7$ \\
\hline
\end{tabular}

Gaseous fuel affects volumetric efficiency of a PFI engine, between 10 and $15 \%$ is lost depending on engine optimisations. The use of a supercharger is necessary to keep output power and torque comparable to that of the alternative gasoline version.

\section{STOICHIOMETRIC APPROACH}

At present, the selection of combustion mode, stoichiometric or lean burn, corresponds to a choice between fuel efficiency and low exhaust emissions.

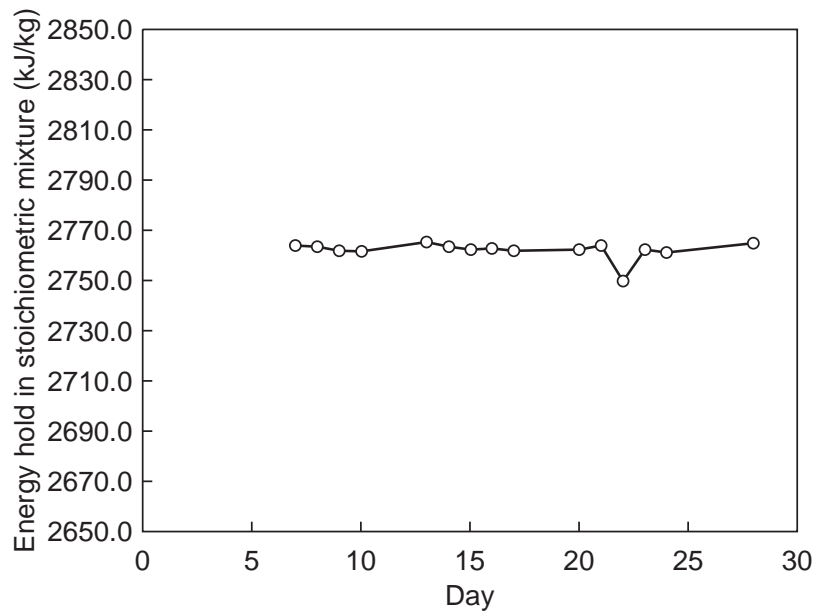

Figure 2

Energy in a NG/air stoichiometric mixture. 


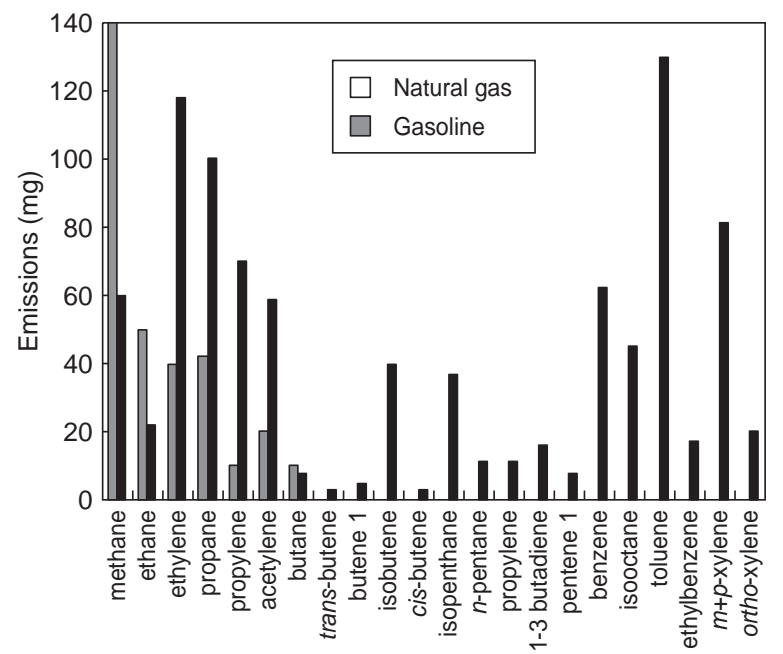

Figure 3

Comparison of unburned hydrocarbon emissions for the same engine running on gasoline and on natural gas (small BI-fuel vehicle).

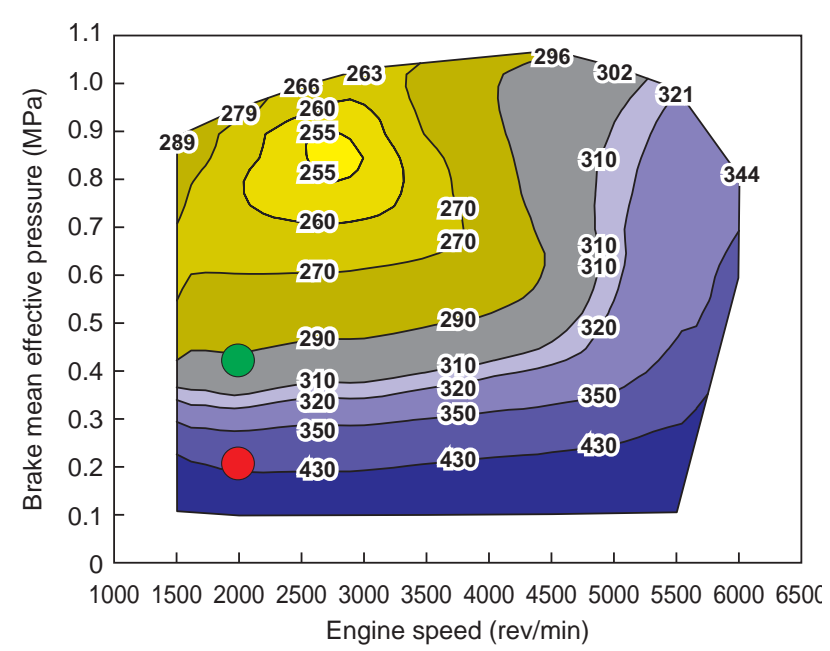

Figure 4

Specific consumption for a conventional medium size SI-FPI gasoline engine.
The stoichiometric approach is more suitable to cope with stringent emission regulation, using proven three-ways catalyst technology. Moreover, for a dedicated natural gas engine, the penalty in terms of consumption is acceptable, with higher exhaust temperature helpful to reduce unburned hydrocarbon during the cold start-up running.

Figure 3 gives a comparison of unburned hydrocarbon emissions for the same engine, running on gasoline and on natural gas. Notice that for natural gas application, unburned hydrocarbons are mainly composed of methane which has very high stability. Thus, in order to limit the unburned hydrocarbons, it is necessary to apply some management strategies which all lead to fuel consumption increasing. This would not be necessary if standard emissions regulations would impose different limits for methane and nonmethane hydrocarbons.

In the case of downsizing, the drop of performance due to displacement reduction can be partially (not over the complete speed range) removed with stoichiometric turbocharged engine, with fewer penalties to control transient conditions.

\section{DOWNSIZING AND SUPERCHARGING}

Looking at running points in demand to propel a vehicle at constant speed, part loads are mainly used. For instance, a medium size vehicle at constant speed of $70 \mathrm{~km} / \mathrm{h}$ needs an output power of $\sim 7 \mathrm{~kW}$. Nevertheless, specific consumption increases as the load is decreased. For a 21 displacement engine at $2000 \mathrm{rpm}, 7 \mathrm{~kW}$ represents a brake mean effective pressure (BMEP) of 2.1 bar and a specific consumption over $400 \mathrm{~g} / \mathrm{kWh}$ for a conventional gasoline FPI engine (Fig. 4). For a smaller engine with displacement of 11 the BMEP is doubled and the consumption is reduced to $300 \mathrm{~g} / \mathrm{kWh}$ representing a gain of $25 \%$.
This example highlights the benefits when reducing engine size: it enables high engine loads with better fuel consumption and reduces friction losses. Obviously, size reduction has to be limited in order to avoid too high a BMEP (especially for gasoline application: knock sensitivity and pollution).

Nevertheless, reducing swept volume leads to affected performances for naturally aspirated engine in terms of output power and maximum torque. The use of a supercharger could improve natural gas performances. For NG injection, the penalty is more severe due to presence of a gaseous phase, which could affect volumetric efficiency by over $10 \%$.

\section{TECHNICAL FEATURES}

The Smart vehicle offers characteristics suitable for urban transportation: small dimensions, light weight and low consumption helping to reduce $\mathrm{CO}_{2}$ emissions.

Designed by the Suprex Company on behalf of MCC Company, the mechanical features of this 3 cylinder-in-line engine are: $63.5 \mathrm{~mm}$ bore, $63 \mathrm{~mm}$ stroke, $599 \mathrm{cc} \mathrm{swept}$ volume, 9.5:1 gasoline compression ratio. The output performances mentioned below are achieved through use of a GT12 cooled turbocharger produced by AlliedSignal Automotive (Garrett), allowing over-boost conditions. In this case, the intake manifold pressure is regulated to 2 bar for NG instead of 1.8 bar for gasoline:

- output power: $40 \mathrm{~kW}$ at $5250 \mathrm{rev} / \mathrm{min}$;

- maximum torque: $80 \mathrm{Nm}$ from $2300 \mathrm{rev} / \mathrm{min}$ to $4500 \mathrm{rev}$ /min.

The chain drive camshaft in the cylinder head (with hydraulic clearance compensation), actuates the two valves per cylinder, (Pict. 1). 


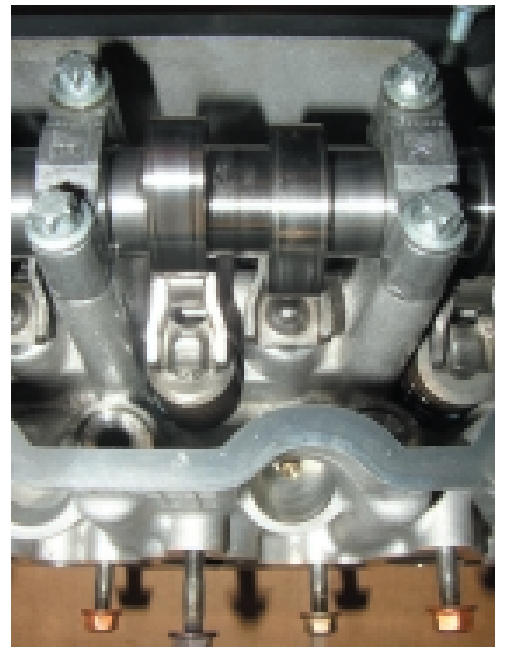

Picture 1

Camshaft in cylinder head.

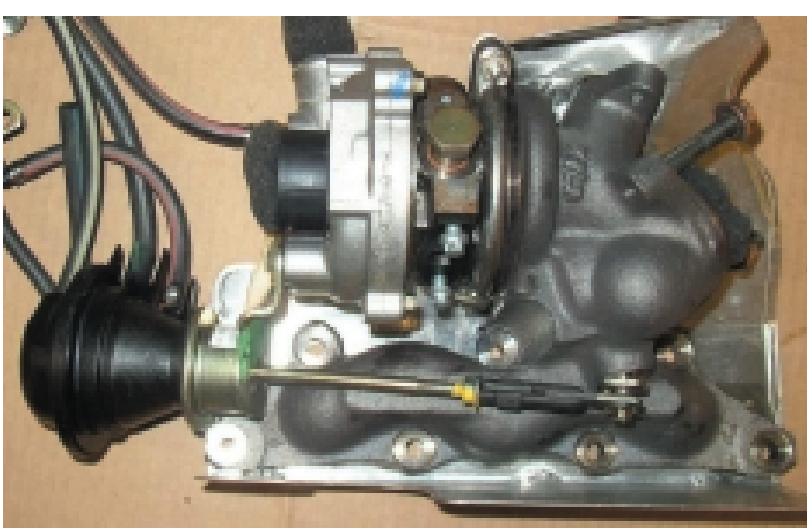

Picture 3

Exhaust manifold.

Two spark plugs per cylinder, the electrodes of which are visible on Picture 2, help to stabilise combustion at delayed spark advance (at low load and low engine speed to light off catalyst during cold condition). The air coming from the compressor is cooled with a dedicated air/air cooler. No EGR circuit is available.

The exhaust manifold has an integrated turbine house as showed on Picture 3. This design reduces thermal losses and makes better use of the exhaust gas energy.

\section{VEHICLE GASOLINE REFERENCE TESTS ON CHASSIS DYNAMOMETER}

The Smart vehicle has been characterised by the Utac Company: aerodynamic and friction losses were determined. Many tests have been carried out by IFP-Lyon in order to establish reference data according to Utac results.

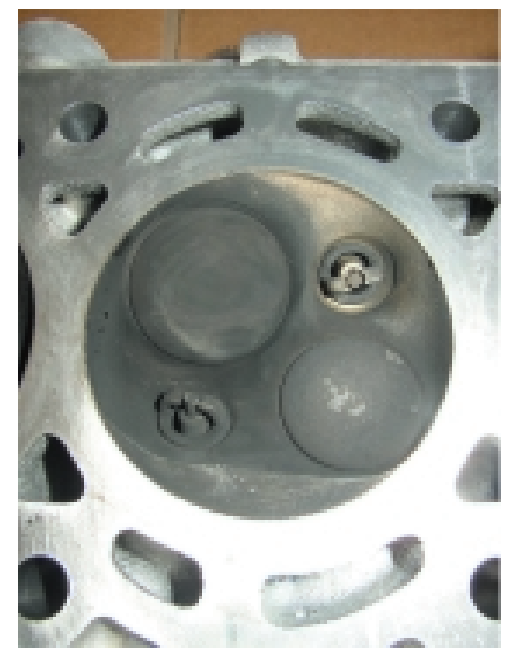

Picture 2

Spark plug and valve location.

Tests confirm that our gasoline vehicle pollutant emissions meet Euro IV regulation, but fuel consumption is higher than official figures. For $\mathrm{CO}_{2}$ emissions (Table 3), the gasoline Smart with a mileage of $3150 \mathrm{~km}$ is quoted $140 \mathrm{~g} / \mathrm{km}$. Checking tests at IFP-Lyon confirm that $\mathrm{CO}_{2}$ performances are quiet surprising, with a noticeable reduction for higher mileage, $132 \mathrm{~g} / \mathrm{km}$ for an aged vehicle $(52000 \mathrm{~km})$.

This reference step is very important to be able to quantify the real impact of using natural gas compared to gasoline.

TABLE 3

Utac and IFP MVEG results

\begin{tabular}{l|c|c|c|c|c}
\hline & $\begin{array}{c}\text { Mileage } \\
\mathrm{km}\end{array}$ & $\begin{array}{c}\mathrm{CO} \\
\mathrm{g} / \mathrm{km}\end{array}$ & $\begin{array}{c}\mathrm{UHC} \\
\mathrm{g} / \mathrm{km}\end{array}$ & $\begin{array}{c}\mathrm{NOx} \\
\mathrm{g} / \mathrm{km}\end{array}$ & $\begin{array}{c}\mathrm{CO}_{2} \\
\mathrm{~g} / \mathrm{km}\end{array}$ \\
\hline Euro IV - 2005 & & 1.00 & 0.10 & 0.08 & \\
\hline Utac results & 3150 & 0.26 & 0.08 & 0.04 & 140.5 \\
IFP results & 3270 & 0.30 & 0.09 & 0.04 & 136.4 \\
\hline IFP results & 52220 & 0.38 & 0.06 & 0.05 & 131.7 \\
\hline
\end{tabular}

Detailed analyses of regulated exhaust emissions confirm a large margin for Euro IV. More than $90 \%$ of unburned hydrocarbons are produced during the first ECE cycle, 70\% of $\mathrm{CO}$ emissions and $60 \%$ of NOx. For fuel consumption, $13 \%$ of total fuel burned during the MVEG cycle is burned during the first ECE cycle, which contributes the most to emissions results.

\section{DEDICATED NATURAL GAS VERSION}

The first development work focused on the engine itself for an optimal use of natural gas characteristics (compression 
ratio, gas rail implementation, gas injectors). Then tests were performed on a test bench with in-house electronic management system ACEbox ${ }^{\mathrm{TM}}$ (Automotive control engine based on XPCtarget ${ }^{\mathrm{TM}}$ ) developed by IFP. Alongside engine optimisation, a vehicle was prepared by modifying the original gearbox and by implementation of gas tanks and a highpressure fuelling line. Finally, the gas engine was installed in the vehicle with the in-board electronic management system based on the ACEbox ${ }^{\mathrm{TM}}$ device.

\section{NATURAL GAS TANK IMPLEMENTATION}

Three tanks build with composite material have been designed and machined by Ullit Company. The total storage capacity is $35 \mathrm{l}$, and the driving range for fuel consumption representative of MVEG cycle is approximately $150 \mathrm{~km}$.

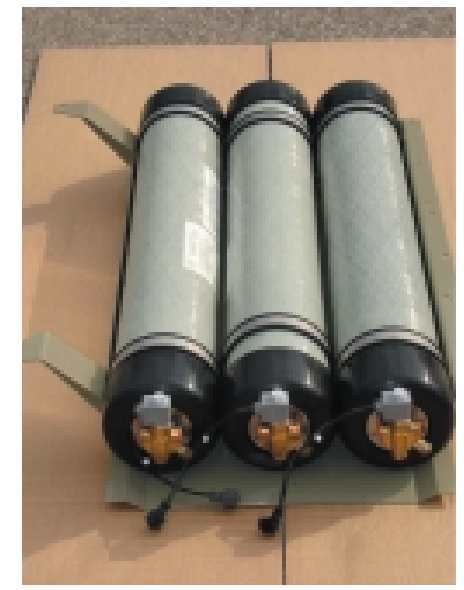

Picture 4

Ullit gas tanks.

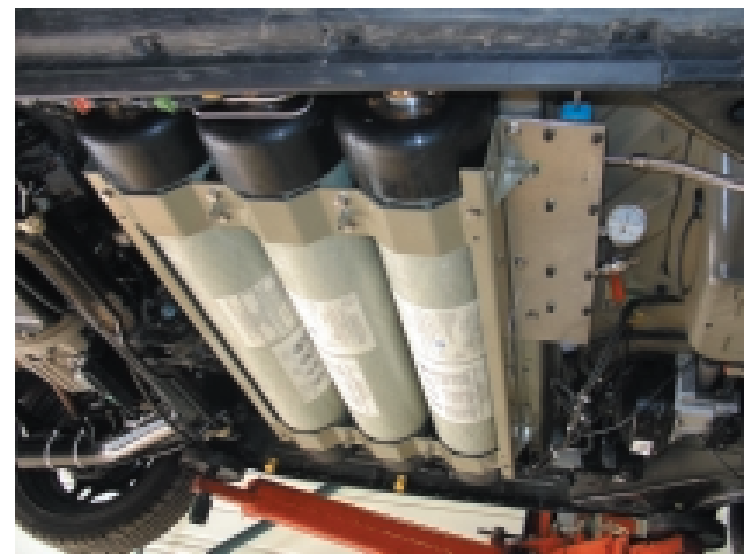

Picture 5

Under floor view.

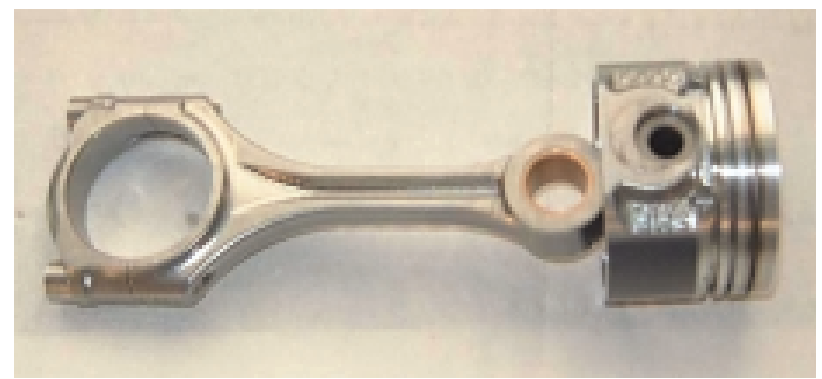

Picture 6

Connecting rod and gas piston.

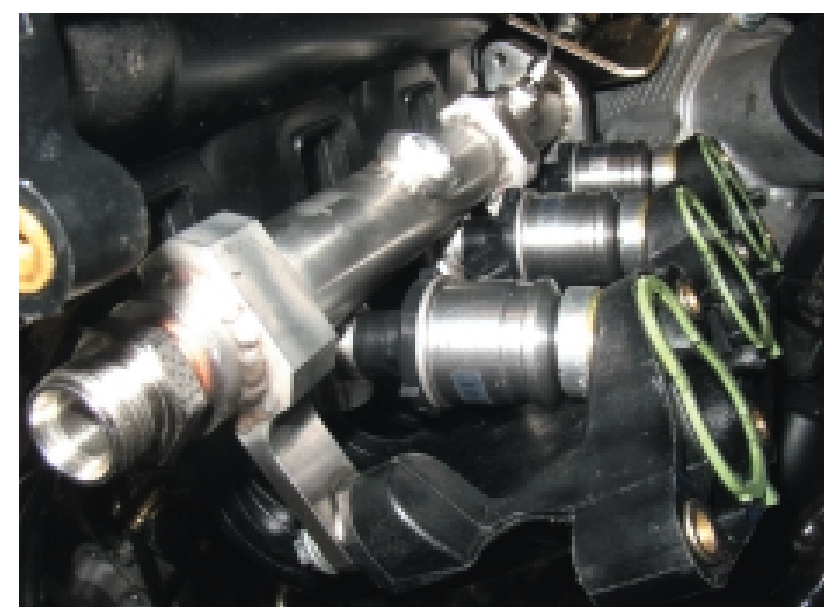

Picture 7

Gas rail in connection with gas injectors.

The tank size is compatible with the space available under floor when the gasoline tank is removed. The ground clearance and volume of the boot are not modified Pictures 4 and 5 .

\section{GAS ENGINE ADAPTATIONS}

The compression ratio was increased from 9.5:1 to 12.0:1. New pistons replace the gasoline ones, able to resist higher in-cylinder pressure, which increases with MBT Advance settings. Connecting rods are strengthened; then, all the mobile parts for gas engine are redesigned Picture 6.

Gas injectors developed by Keihin for the Honda Civic vehicle were selected for the low rail pressure needed useful to reduce leakage after engine switch-off (avoiding flashback and HC peak when starting). The gas pressure reducer Sherex reduces the pressure from over 200 bar (corresponding to filling condition) to 4 bar (at 4 bar sonic flow conditions are maintained under turbocharged conditions). 


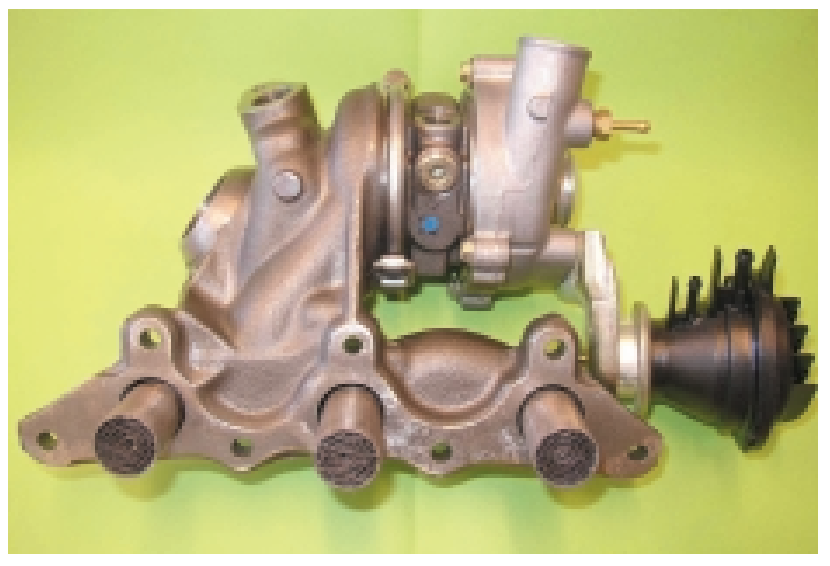

Picture 8

Metallic light-off implementation.

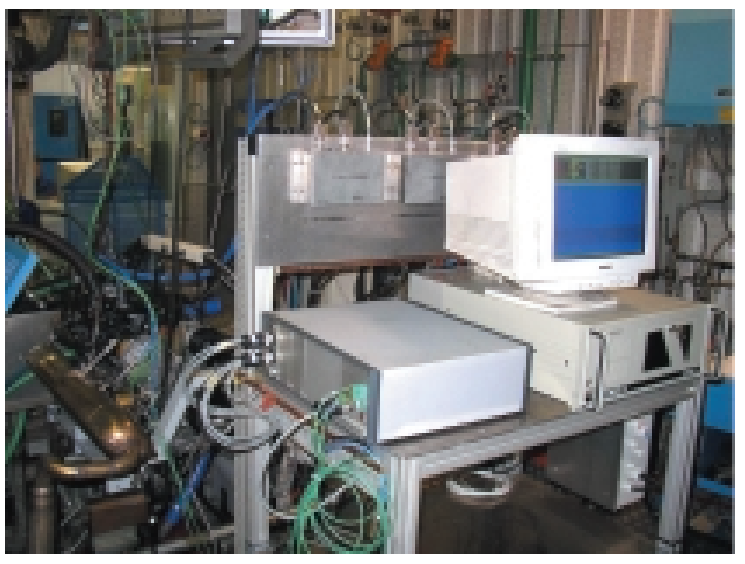

Picture 9

ACEbox $^{\mathrm{TM}}$ system and engine on bench.

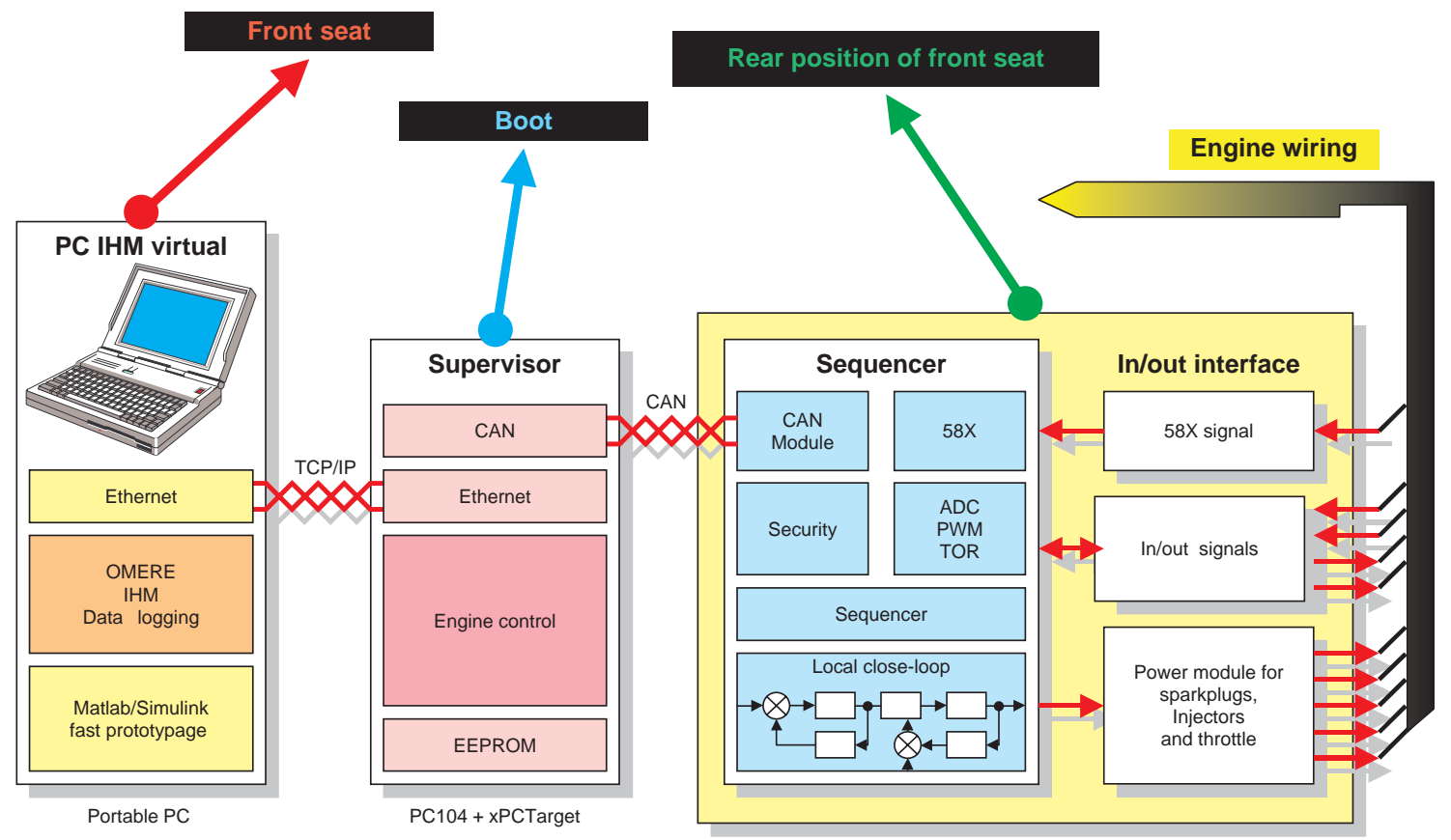

Figure 5

Scheme of on-board system.

The main challenge for the gas rail design is its implementation within the limited space available on the gasoline engine. Picture 7 shows the gas rail in connection with the gas injectors bolted on the intake manifold.

As mentioned, exhaust after-treatment remains an essential stage to succeed in reducing exhaust emissions. In addition to light-off strategies (for instance delayed spark advance) main catalyst formulation and loading have been strongly optimised in order to overcome the high stability of methane. In addition, three small metallic converters located between cylinder-head duct and exhaust manifold (loaded with the same formulation) improve post-treatment efficiency especially during the critical first seconds period after start-up (Pict. 8). 


\section{ON-BOARD ENGINE MANAGEMENT SYSTEM}

To control engine performance and to be free from any engine management strategy implementation, IFP has decided, in accordance with the partners involved in the project, to manage the gas engine using its own device.

At first the ACEbox ${ }^{\mathrm{TM}}$ system designed by IFP, able to drive the engine both on bench and on vehicle, has been used for engine bench tests. Mapping on steady state conditions is optimised before data implementation for vehicle tests (Pict. 9).

The on-board system developed in collaboration with $\mathrm{FH}$ Electronics Company is based on the ACEbox ${ }^{\mathrm{TM}}$ system and is composed of a Supervisor computer located in the boot and a sequencer computer, located back of the front right seat, in charge of timing and of input/output signal management (Fig. 5).

As shown on pictures 10 and 11, small EMS do not reduce available luggage space. For a small vehicle such as the Smart, maintaining acceptable luggage space is important. At the end of the optimisation tests, the supervisor computer (the largest one) will be removed.

\section{TESTS ON ENGINE BENCH: COMPARISON BETWEEN GASOLINE AND NATURAL GAS VERSIONS}

Results obtained using natural gas are extremely promising compared to gasoline reference performances. At full load conditions, the potential of natural gas as a high octane number fuel is demonstrated: in Figure 6, spark advance timing and equivalence ratio are shown versus speed for both natural gas and gasoline settings.
From $2000 \mathrm{rev} / \mathrm{min}$, gasoline spark advance must be reduced due to knock limit, and from 2500 rev/min enrichment is necessary to control exhaust temperature which drastically increases when spark advance is delayed. The mean gap reaches $8 \mathrm{CA}$ while equivalence ratio for $\mathrm{NG}$ operation is stoichiometric at all engine speeds.

One of the major drawbacks of gasoline settings is an increase of fuel consumption. Figure 7 compares thermal efficiency at full load taking into account over-enrichment and spark timing for gasoline. At low engine speed, reduction of volumetric efficiency, due to natural gas injection, affects brake mean effective pressure. The turbocharger is able to compensate airflow reduction from $2600 \mathrm{rpm}, 300 \mathrm{rpm}$ higher than for gasoline. New strategies under development for better management of the wastegate should reduce this difference, but as of now, these performances with natural gas guarantee transient vehicle behaviour in accordance with client expectation.

One other solution to improve torque at low speed is electrical assistance. A light hybrid approach, based on a $3 \mathrm{~kW}$ motoralternator, should supply extra-power for peak load condition and so totally compensate the penalty as showed in Figure 7.

For the same load, thermal efficiency for natural gas is 6 points higher than for gasoline, an increase of $25 \%$ which reveals the impact of settings and the favourable effect of the increased compression ratio. This benefit is noticeable for a wide engine speed range.

The second major effect is on exhaust emissions, both for NOx and unburned hydrocarbon as showed in Figure 8. For stoichiometric mixture, NOx emissions with natural gas are lower due to combustion velocity and despite delayed spark advance timing for gasoline. Unburned hydrocarbon emissions increase for gasoline as soon as the mixture is rich, whereas they stay low for natural gas.

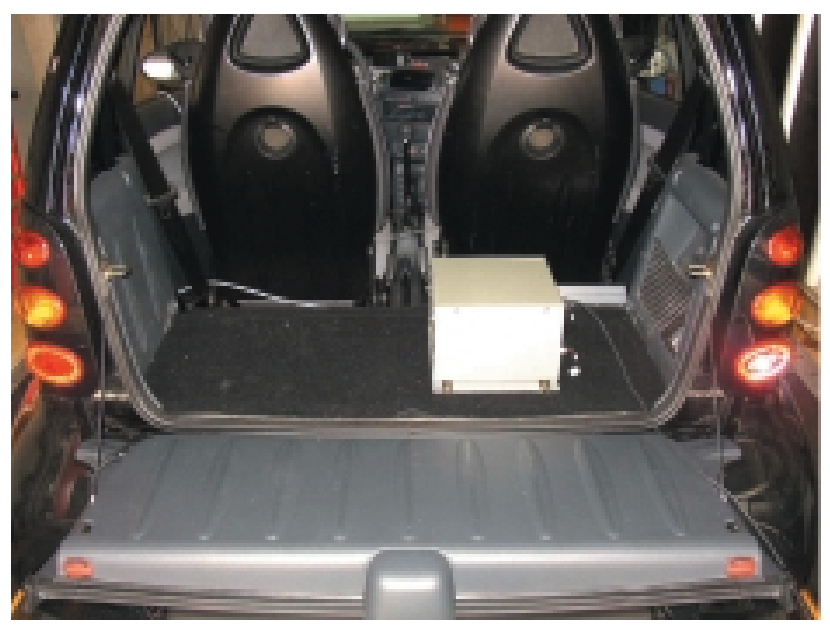

Picture 10

Boot of demonstrator with on-board EMS

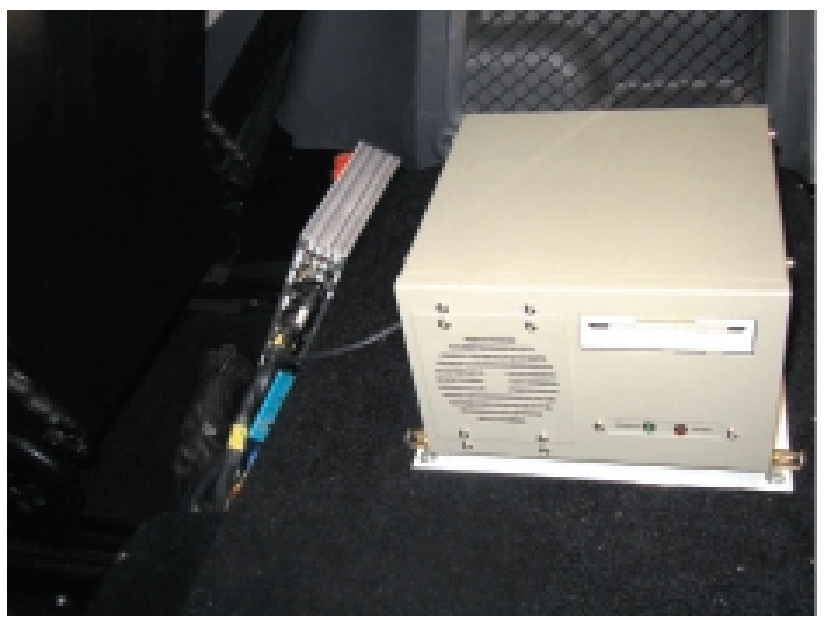

Picture 11

Supervisor and sequencer computers. 
Full load comparison

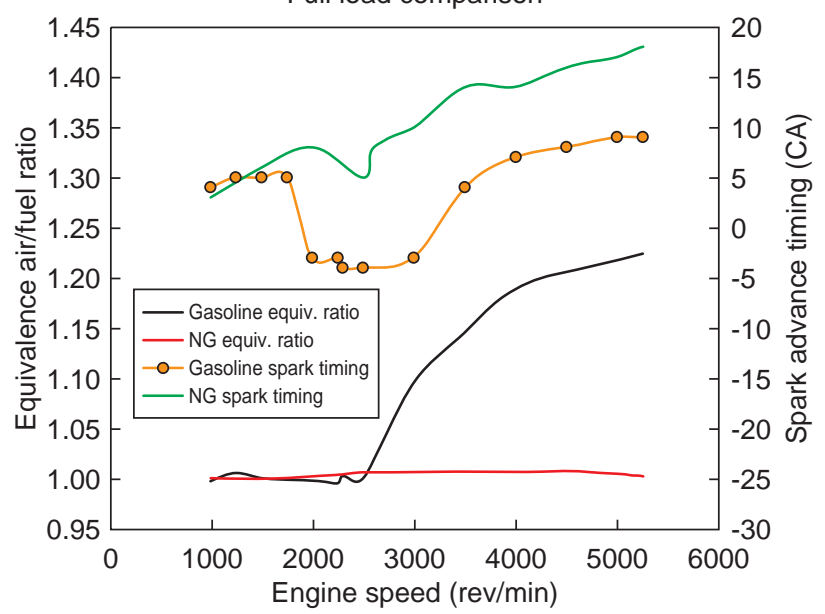

Figure 6

Equivalence ratio and spark timing at full load (gasoline and NG).

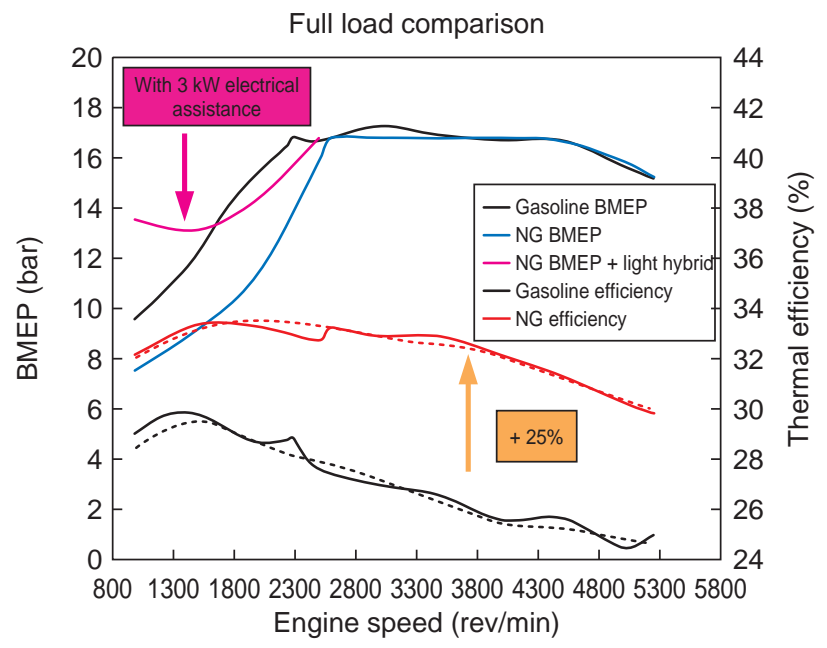

Figure 7

BMEP and thermal efficiency at full load (gasoline and NG).

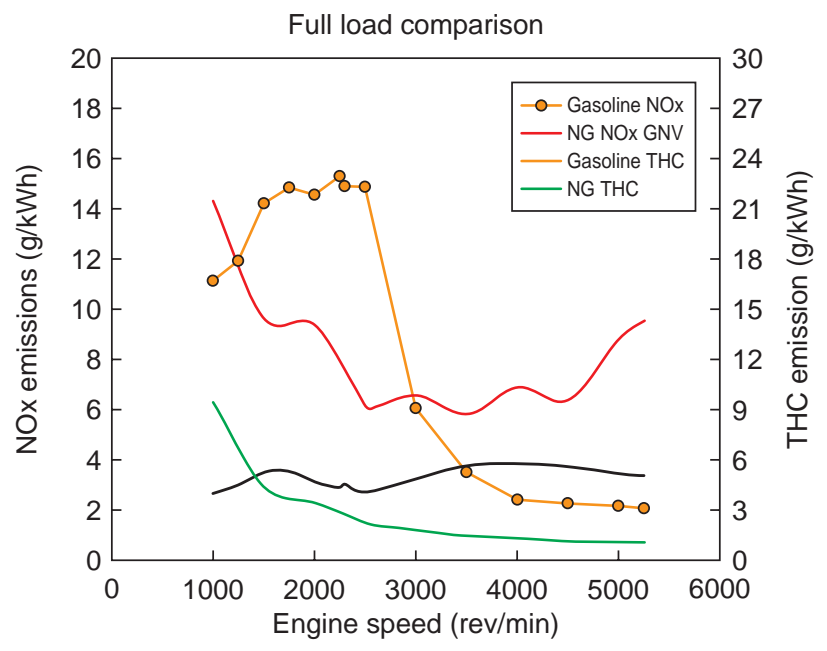

Figure 8

NOx and UHC raw emissions at full load (gasoline and NG).

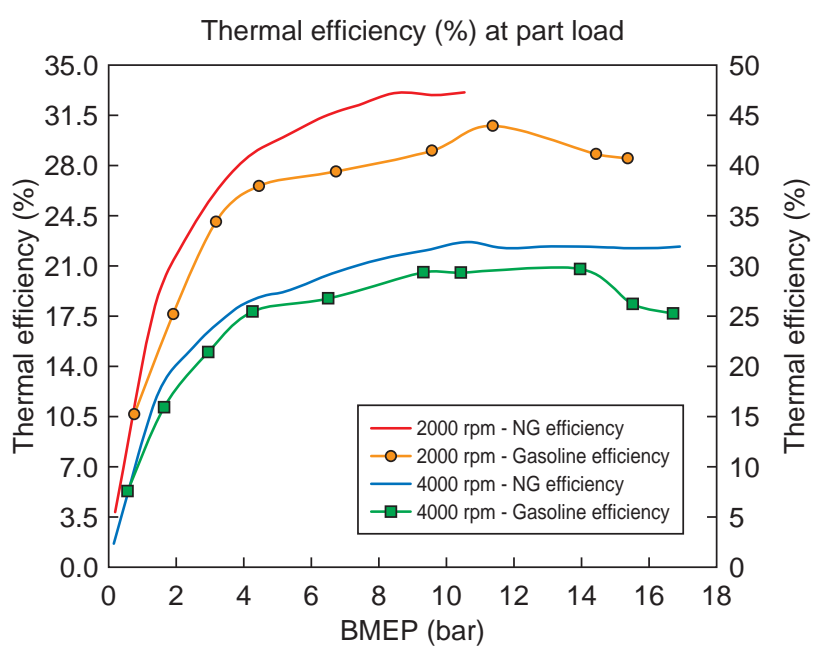

Figure 9

Thermal efficiency at part load.
Results at part load conditions also distinguish natural gas engine. At $2000 \mathrm{rpm}$, Figure 9, thermal efficiency for natural gas exceeds that of gasoline by a large margin from 2 bar to 8 bar (BMEP). For higher load, the variation is reduced as expected: indeed, for this engine speed, stoichiometric condition and spark advances settings close to MBT are used both for natural gas and gasoline.

At $4000 \mathrm{rpm}$, thermal efficiency is higher for natural gas with a difference that is enhanced as the load becomes higher (over-enrichment and advance strategies for gasoline).

The difference between gasoline and natural gas specific fuel consumption calculated for the same fuel is plotted in Figure 10. As seen, the gasoline engine consumption is noticeably higher at low and high loads. The lowest difference calculated is $3 \mathrm{~g} / \mathrm{kWh}$ at $1500 \mathrm{rev} / \mathrm{min}$ and $3 \mathrm{bar}$ (star mark). For the MVEG cycle, some steady state running points are plotted (circle marks), mainly located in the highest difference area. 
Based on those results obtained on engine test bench, simulations performed with AMESim software reveal that the target in terms of $\mathrm{CO}_{2}$ emissions (lower than $100 \mathrm{~g} / \mathrm{km}$ on MVEG cycle) is attainable with confidence.

Calibration tests on a chassis dynamometer bench are in progress and reveal a considerable potential for this demonstrator vehicle to cope with the $\mathrm{CO}_{2}$ target.

\section{CONCLUSION}

This research, carried out in a partnership between $G a z$ de France and IFP with funding from Ademe, confirms the great potential of natural gas when used as a dedicated fuel on a downsized engine. Tests performed with vehicle confirm that; targets of $\mathrm{CO}_{2}$ emissions less than $100 \mathrm{~g} / \mathrm{km}$ are efficient.

The new gas tanks made of composite material are implemented so that the bootspace inside the vehicle is not affected. The extra-weight is limited and no more than $45 \mathrm{~kg}$.

The development of in-house on-board electronic management system represents a strategic stage to be able to assess the potential of our approach focusing on an optimisation of vehicle behaviour while meeting Euro IV regulations. For this challenge, the installation of extra metallic light-off catalysts should be effective.

Finally, the development of the NG Smart demonstrator is in line with the IFP strategy that considers that the NG pathway is one of the most efficient ways to reduce both greenhouse gas and pollutants emissions from transportation.

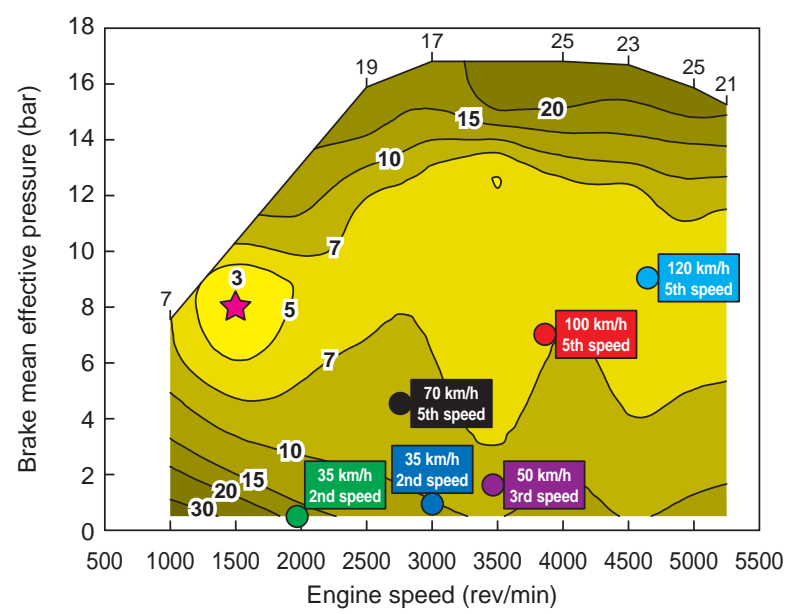

Figure 10

BSFC difference between gasoline en NG engine.

\section{ACKNOWLEDGEMENTS}

On behalf of the study, IFP would like to acknowledge $G a z$ de France for its cooperation and Ademe for its interest and confidence in this project and for its financial support.

\section{REFERENCES}

1 Heitzer, M., Langen, P., Kramer, F. and Meyer, O. (2000) Achieving Low Emissions and High engine Efficiency with Natural Gas, IANGV Yokohama.

2 Sun, X., Wiedmann, T. and Hussain, S., Fuel management and exhaust emissions of light-and heavy-duty trucks operating on CNG and LPG. SAE Paper 971661.

3 Suga, T., Muraishi, T. and Bienenfeld, R. (2000) Potential of a low-emission natural gas vehicle for the 21 st century. IANGV Yokohama.

4 Tilagone, R., Monnier, G., Satre, A., Lendresse, Y., Personnaz, J., Cullerier, D. and Turin, F. (2000) Development of a lean-burn natural gas powered vehicle based on a direct-injection diesel engine. SAE Paper 2000-01-1950.

5 Johansson, B., and Olsson, K. (1995) Combustion Chambers for Natural Gas SI Engines Part I : Fluid Flow and Combustion. SAE Paper 950469.

6 Olsson, K., and Johansson, B. (1995) Combustion Chambers for Natural Gas SI Engines Part I : Combustion and Emissions. SAE Paper 950517.

7 Tilagone, R., Monnier, G., Chaouche, A., Baguelin, Y. and De Chauveron S. (1996) Development of a high efficiency, low emission SI-CNG bus engine, SAE Paper 961080 , Detroit (USA).

8 Gaz de France (1993) Combustibles gazeux et principes de la combustion (BT104).

9 Union européenne (2000) Bilan Auto-oil.

10 Cornetti G (1999) Alternative fuels: the natural gas. ATA, 52, Nov.-Dec..

11 Cedigaz (2002) Natural Gas in the World.

12 Guibet, J.C. (1997) Carburants et Moteurs, 1 et 2.

13 Journal Officiel des Communautés Européennes (2001) L107/10. Directive 2001/27/CE de la Commission du 10 avril.

14 Norm ISO 15403 (200) Gaz naturel - Désignation de la qualité de gaz naturel pour usage comme carburant comprimé pour véhicules.

15 Norm ISO 6976 (1997) Gaz naturel - Calcul du pouvoir calorifique, de la masse volumique, de la densité relative et de l'indice de Wobbe à partir de la composition.

16 IANGV (International Association for Natural Gas Vehicles) (2000) Emissions Report, Part 2: Fuel Properties.

17 Buthker E. (2000) World Wide NGV Standards and Regulations. Session 2A. IANGV, October 17-19.

18 AFGNV (Association Française du gaz naturel pour véhicules) (2001) Rapport d'activité.

19 P. Zanetta (2001) GNV : une première étape est franchie. Pétrole et gaz informations, $\mathrm{n}^{\circ} 1755$.

20 Plouchard G. (2002) Le gaz naturel véhicules : les enjeux énergétiques et environnementaux de son développement durable. Rapport du Groupe de travail Energie Environnement de l'AFGNV.

21 Nylund, N.O., Laurikko, J. and Ikonen, M. Pathways for natural gas into advanced vehicles. International Association for Natural Gas Vehicles Report, (copies at) www.iangv.org 
22 Argonne National Lab. 1-2 (2001) Well to Wheel Energy use and Green Gas Emissions of Advanced Fuel/Vehicle Systems - North American Analysis.

23 Weiss, M.A., Heywood, J.B., Drake, E.M., Schafer, A. and AuYeung, F.F. (2000) On the Road in 2020. A life -cycle analysis of new automobile technologies. MIT EL 00-003.

24 Choudhury, R. (2002) Well to Wheel Analysis of Energy use and Greenhouse Gas Emissions of Advanced Fuel/Vehicle Systems. www.lbst.de/gm-wtw

25 European commission (2001) Livre Blanc. La politique européenne des transports à l'horizon 2010. L'heure des choix. COM(2001)370.
26 Ly, H. (2002) Effects of Natural Gas Composition Variations on the Operation, Performance and Exhaust Emissions of natural Gas-Powered Vehicles. IANGV.

27 European commission (2002) Livre Vert. Vers une stratégie européenne de sécurité d'approvisionnement énergétique, $\operatorname{COM}(2002) 321$.

28 Orselli, J. (1992) Énergies nouvelles pour l'automobile.

29 Rouveirolles, P. (2000) Les spécifications des carburants GPL et GNV. Euroforum.

30 Douaud, A., (2001) Quelles énergies pour l'automobile de demain. SIA

Final manuscript received in December 2004 